

DEN NORSKE LEGEFORENING

\title{
Barn med medfødt hørselstap - en sårbar gruppe
}

KRONIKK

\section{KRISTIN HOLSETH}

E-post: kholse@ous-hf.no

Kristin Holseth er spesialist i barne- og ungdomspsykiatri og overlege ved Nasjonal

behandlingstjeneste for hørsel og psykisk helse, Klinikk for psykisk helse og avhengighet, Oslo universitetssykehus.

Forfatteren har fylt ut ICMJE-skjemaet og oppgir ingen interessekonflikter.

\section{TONE STOKKEREIT MATTSON}

Tone Stokkereit Mattson er overlege ved Avdeling for øye, øre-nese-hals og kjevekirurgi, Ålesund sjukehus

Forfatteren har fylt ut ICMJE-skjemaet og oppgir ingen interessekonflikter.

Barn med medfødt eller tidlig utviklet sensorinevrogent hørselstap har økt risiko for andre nevroutviklingsavvik, blant annet synsvansker, kognitive og motoriske vansker. Systematisk kartlegging og oppfølging av barn med påvist sensorinevrogent hørselstap er viktig for å kunne avdekke slike problemer på et tidlig tidspunkt.



Illustrasjon: Lisbeth Moen

Medfødte eller tidlig utviklede sensorinevrogene hørselstap skyldes enten arv, miljøfaktorer eller en kombinasjon. Ved opptil 6o \% av tilfellene finner man en genetisk årsak, hvorav ca. $30 \%$ er en del av et syndrom og ca. 70 \% er ikke-syndromale, dvs. at hørselstapet er den eneste funksjonshemningen (1). Ca. 40 \% skyldes miljøbetingede årsaker som asfyksi, hyperbilirubinemi, prematuritet, meningitt, ototoksiske medikamenter og 
medfødte infeksjoner (med cytomegalovirusinfeksjon som den hyppigste årsaken).

En stor andel av sensorinevrogene hørselstap som skyldes medfødt cytomegalovirusinfeksjon, debuterer sent og blir ikke fanget opp ved nyfødtscreening (2). Alle infeksjoner hos barn før eller like etter fødselen (såkalte TORCH-infeksjoner: toksoplasmose, rubella, cytomegalovirusinfeksjon, herpes simplex) kan føre til sensorinevrogent hørseltap og hjerneorganisk patologi (3). I Nasjonal faglig retningslinje for utredning og oppfølging av hørsel hos små barn (o-3 år) anbefales det å kun tilby cytomegalovirusdiagnostikk der årsaken til hørselstapet er ukjent. Siden fokus nå er på cytomegalovirusinfeksjon, testes det ikke alltid for andre agens. Dette kan bidra til underdiagnostikk av årsaker til hørselstap.

De kjente miljøbetingede årsakene til sensorinevrogene hørselstap er de samme som kan gi nevroutviklingsvansker hos barn, og de cerebrale MR-funnene kan være uspesifikke. I en systematisk oversiktsartikkel over nevroutviklingsmessige senskader etter premature eller neonatale insult, konkluderer forfatterne med at $31 \%$ av barna utvikler minimum én senskade (4). De vanligste er kognitive vansker, generelt forsinket utvikling eller lærevansker (59\%), cerebral parese (21\%), hørselstap (20\%), synsvansker (18\%) og vansker med grovmotorikk og koordinering (8\%).

\section{Udiagnostiserte tilleggsvansker}

Ved Nasjonal behandlingstjeneste for hørsel og psykisk helse (NBHP) ved Oslo universitetssykehus behandles årlig ca. go barn og unge med sensorinevrogene hørselstap og psykiske vansker i aldersgruppen o-18 år.

Vi erfarer at flere av de henviste barna har tilleggsvansker som ikke er diagnostisert fra før. Dette kan være motoriske koordineringsvansker, eksekutive vansker, sosiale vansker, lærevansker, samsynsvansker og skjeling. Barnas helseplager har ofte blitt oppfattet som en konsekvens av hørselstapet og har ikke blitt behandlet eller tilrettelagt for.

Flere av barna med slike plager har tatt cerebral MR, med hyppige funn av bl.a. periventrikulær leukomalasi (PVL), utvidede ventrikler og forandringer i hvit substans. Barna med funn på cerebral MR blir undersøkt av pediater, enten i sammenheng med innleggelse ved nyfødtintensivavdeling eller som ledd i utredning for cochleaimplantat. Ved normal nevromotorisk utvikling har pediatrisk oppfølging ofte blitt avsluttet fordi MRfunnet er vurdert som uspesifikt og uten prediktiv verdi.

Årsaksutredningen av hørselstapet til barn som henvises til NBHP, varierer fra å være minimal til bred genetisk og somatisk utredning, inkludert cerebral MR. Oppfølgingen av andre forhold enn hørselstap er også variabel, til tross for høy grad av komorbiditet av andre nevroutviklingsavvik.

\section{Cerebral MR og hørselstap}

Få studier har sett på sammenhengen mellom uspesifikke funn på cerebral MR og risiko for å utvikle senskader hos barn med sensorinevrogent hørselstap. Chilosi og medarbeidere fant at 48 av 100 barn med slikt hørselstap hadde nevroutviklingsvansker (5). I tillegg ble det notert at ytterligere 19 barn hadde språkforstyrrelse, som ikke ble betegnet som en tilleggsvanske i denne studien. Risikoen for tilleggsvansker var doblet ved affeksjon av hvit substans påvist ved MR. Den var også noe høyere ved migrasjonsforstyrrelser (5).

Uavhengig av hørselsstatus har man i flere studier sett på sammenhengen mellom uspesifikke funn på cerebral MR hos barn og risiko for å utvikle senskader. Resultatene har vært sprikende: 7,9-39,4\% (6-10). Barn med kjent risiko for hjerneorganisk affeksjon, men uten patologiske funn på cerebral MR kan også ha nevroutviklingsvansker (11).

De sprikende resultatene kan forklare at patologiske MR-funn alene ikke fører til videre oppfølging av barna. Imidlertid kan metodiske forskjeller i radiologiske opptaksmetoder, ulike utfallsparametere og ulik oppfølgingstid vanskeliggjøre sammenligning av studiene. 
Den teknologiske utviklingen har ført til bedre diagnostisering ved bruk av cerebral MR i dag enn for 20-30 år siden. Det er behov for studier med lengre oppfølgingstid (til skole, ev. ungdomsalder) og som inkluderer balanse, koordinasjon, syn, kognisjon og psykiske vansker.

Dettmann og medarbeidere viser at barn med miljøbetinget sensorinevrogent hørselstap har dårligere reseptiv språkforståelse etter operasjon med cochleaimplantat enn barn med genetisk ikke-syndromalt hørselstap, og de har høyere grad av komorbiditet (59\% vs. 8 \%) (12).

Det er internasjonal enighet om at tidlig diagnostisering og oppfølging av hørselstap er viktig for at barna skal ha en god språkutvikling $(13,14)$. Andre faktorer som er vist å ha en positiv innvirkning på språkutviklingen, er blant annet høyt utdanningsnivå hos mor og at barnet ikke har tilleggsvansker (14). En stor andel av barna har imidlertid dårlig språkutvikling uten at man har funnet årsaken til det. Vurderingen av cerebral MR og etiologi kan muligens bidra til en klarere forståelse.

\section{Hørselstap og nevroutviklingsvansker}

30-60 \% av barn med sensorinevrogent hørselstap har i tillegg synsproblemer, kognitive, motoriske, emosjonelle, atferdsmessige eller andre vansker (15-18). Spesielt synsvansker er assosiert med hørselstap (40-6o \%). Disse er ofte udiagnostisert og omfatter korrigerbare samsynsvansker, skjeling og refraksjonsvansker eller ukorrigerbare skader på synsnerven eller retinopati (16).

Få studier har sett på sammenheng mellom årsak til sensorinevrogene hørselstap og barns utvikling, men studier av de enkelte miljøbetingede årsaker som prematuritet, asfyksi og medfødt cytomegalovirusinfeksjon har vist høy grad av komorbide nevroutviklingsvansker, som også kan ha et progressivt forløp. Etter vår mening benyttes ikke denne kunnskapen godt nok. Oppfølging av premature barn viser at undersøkelse og vurdering ved to års alder har begrenset nytte for å predikere kognitiv og motorisk funksjon ved fem års alder (19).

Vi mener at Nasjonal faglig retningslinje bør endres slik at eventuelle tilleggsvansker oppdages tidligst mulig

Dersom cerebral parese, prematuritetsretinopati og psykisk utviklingshemning utelukkes, antas barnet ofte å være uten tilleggsvansker, til tross for klossethet, samsyns- og lærevansker m.m. Vanskene barnet har blir i stedet tilskrevet hørselstapet (såkalt diagnostisk overskygging). Når hørselstapet påvises i småbarnsalder, kan det innebære et progressivt forløp som også kan gjelde andre funksjonsområder. Da bør man være ekstra årvåkne for å avdekke utvikling av eventuelle tilleggsvansker.

Døve barn av døve foreldre har i større grad genetisk ikke-syndromalt hørselstap. Disse har dermed mindre risiko for nevroutviklingsvansker enn barn av hørende foreldre (20).

\section{Klumsethet og psykopatologi}

Mange barn med sensorinevrogent hørselstap har motoriske vansker, uten å ha cerebral parese (21). Disse regnes ofte ikke som tilleggsvansker, men opptrer ofte sammen med sosiale vansker (21). Motorisk klumsethet, uavhengig av hørselsstatus, er gjerne knyttet til psykiske vansker, som autismespekterforstyrrelse og ADHD (22), angstproblematikk (23) og nedsatt livskvalitet (24). Tidlig avdekking av slike vansker og målrettet trening kan bidra til $\emptyset \mathrm{kt}$ mestringsfølelse og livskvalitet hos barnet.

\section{Psykisk helse}

Det er høyere grad av psykopatologi hos barn med sensorinevrogent hørselstap enn blant typisk hørende barn, med prevalens 20-50\% (25). Prevalensen er tre ganger høyere blant barn med sensorinevrogent hørselstap og tilleggsvansker enn hos hørselshemmede barn 
uten tilleggsvansker (26). Barn med hørselstap kommer senere til behandling for psykiske vansker enn typisk hørende barn (18). Det er ikke døvheten i seg selv som bidrar til de psykiatriske problemene. Lavt evnenivå, svak språkforståelse (på barnets foretrukne språk, enten det gjelder tegnspråk eller verbalspråk) og tilleggsvansker er assosiert med psykososiale vansker $(17,18,26)$.

\section{Anbefalinger for oppfølging}

Vi mener at Nasjonal faglig retningslinje for utredning og oppfølging av hørsel hos små barn (o-3 år) bør endres slik at eventuelle vansker i tillegg til hørselstapet oppdages tidligst mulig. Det bør gis et tverrfaglig tilbud bestående av pediater, øre-nese-hals-lege, radiolog, audiopedagog, øyelege, ortoptist, fysioterapeut, sosionom, psykolog og barne- og ungdomspsykiater for en helhetlig vurdering og oppfølging etter påvist sensorinevrogent hørselstap. Fokus bør være spesielt rettet mot synsfunksjon inkludert samsyn og skjeling, balanse og koordinasjon, kognisjon og psykisk helse ved systematisk kartlegging og oppfølging opp til ungdomsalder.

En grundig årsaksutredning inkludert vurdering av cerebral MR kan bidra til å avdekke hvilke barn som har risiko for komorbide vansker

En grundig årsaksutredning inkludert vurdering av cerebral MR kan bidra til å avdekke hvilke barn som har risiko for komorbide vansker. Ved «ukjent» årsak, men med påvist patologi på cerebral MR kan en pre/perinatal årsak til både hjerneskaden og hørselstapet ikke utelukkes. Barnet bør da følges tett for å fange opp eventuelle tilleggsvansker.

\section{LITTERATUR:}

1. Alford RL, Arnos KS, Fox M et al. American College of Medical Genetics and Genomics guideline for the clinical evaluation and etiologic diagnosis of hearing loss. Genet Med 2014; 16:347-55. [PubMed][CrossRef]

2. Dahle AJ, Fowler KB, Wright JD et al. Longitudinal investigation of hearing disorders in children with congenital cytomegalovirus. J Am Acad Audiol 2000; 11: 283-9o. [PubMed]

3. Alzahrani M, Tabet P, Saliba I. Pediatric hearing loss: common causes, diagnosis and therapeutic approach. Minerva Pediatr 2015; 67: 75-90. [PubMed]

4. Mwaniki MK, Atieno M, Lawn JE et al. Long-term neurodevelopmental outcomes after intrauterine and neonatal insults: a systematic review. Lancet 2012; 379: 445-52. [PubMed][CrossRef]

5. Chilosi AM, Comparini A, Scusa MF et al. Neurodevelopmental disorders in children with severe to profound sensorineural hearing loss: a clinical study. Dev Med Child Neurol 2010; 52: 856-62. [PubMed][CrossRef]

6. Keunen K, Kersbergen KJ, Groenendaal F et al. Brain tissue volumes in preterm infants: prematurity, perinatal risk factors and neurodevelopmental outcome: a systematic review. J Matern Fetal Neonatal Med 2012; 25 (suppl 1): 89-100. [PubMed][CrossRef]

7. Jarjour IT. Neurodevelopmental outcome after extreme prematurity: a review of the literature. Pediatr Neurol 2015; 52:143-52. [PubMed][CrossRef]

8. Pagani G, Thilaganathan B, Prefumo F. Neurodevelopmental outcome in isolated mild fetal ventriculomegaly: systematic review and meta-analysis. Ultrasound Obstet Gynecol 2014; 44: 254-6o. [PubMed][CrossRef]

9. Baron IS, Litman FR, Ahronovich MD et al. Late preterm birth: a review of medical and neuropsychological childhood outcomes. Neuropsychol Rev 2012; 22: 438-50. [PubMed][CrossRef]

10. Meher S, Hernandez-Andrade E, Basheer SN et al. Impact of cerebral redistribution on neurodevelopmental outcome in small-for-gestational-age or growth-restricted babies: a systematic review. Ultrasound Obstet Gynecol 2015; 46:398-404. [PubMed][CrossRef]

11. Giannattasio A, Bruzzese D, Di Costanzo P et al. Neuroimaging profiles and neurodevelopmental 
outcome in infants with congenital cytomegalovirus infection. Pediatr Infect Dis J 2018; 37: 1028-33. [PubMed][CrossRef]

12. Dettman S, Pocsidio S, Choo D. Language outcomes for children using cochlear implants who have connexin-related cause of hearing loss compared to groups who have non-syndromic genetic and environmentally-acquired hearing loss. Poster. Washington, DC: CI2018 Emerging Issues in Cochlear Implantation Symposium, 2018.

13. Ching TY. Is early intervention effective in improving spoken language outcomes of children with congenital hearing loss? Am J Audiol 2015; 24:345-8. [PubMed][CrossRef]

14. Yoshinaga-Itano C, Sedey AL, Wiggin M et al. Early hearing detection and vocabulary of children with hearing loss. Pediatrics 2017; 140: e20162964. [PubMed][CrossRef]

15. Russ SA, Poulakis Z, Barker M et al. Epidemiology of congenital hearing loss in Victoria, Australia. Int J Audiol 2003; 42:385-9o. [PubMed][CrossRef]

16. Nikolopoulos TP, Lioumi D, Stamataki S et al. Evidence-based overview of ophthalmic disorders in deaf children: a literature update. Otol Neurotol 2006; 27 (suppl 1): S1-24, discussion S2O.

[PubMed][CrossRef]

17. van Gent T, Goedhart AW, Hindley PA et al. Prevalence and correlates of psychopathology in a sample of deaf adolescents. J Child Psychol Psychiatry 2007; 48: 950-8. [PubMed][CrossRef]

18. van Gent T, Goedhart AW, Treffers PD. Characteristics of children and adolescents in the Dutch national in- and outpatient mental health service for deaf and hard of hearing youth over a period of 15 years. Res Dev Disabil 2012;33:1333-42. [PubMed][CrossRef]

19. Leversen KT, Sommerfelt K, Elgen IB et al. Prediction of outcome at 5 years from assessments at 2 years among extremely preterm children: a Norwegian national cohort study. Acta Paediatr 2012; 101: 264-70. [PubMed][CrossRef]

20. Gentili N, Holwell A. Mental health in children with severe hearing impairment. Adv Psychiatr Treat 2011; 17: 54-62. [CrossRef]

21. Fellinger MJ, Holzinger D, Aigner M et al. Motor performance and correlates of mental health in children who are deaf or hard of hearing. Dev Med Child Neurol 2015; 57: 942-7. [PubMed][CrossRef]

22. Gillberg C, Kadesjö B. Why bother about clumsiness? The implications of having developmental coordination disorder (DCD). Neural Plast 2003; 10: 59-68. [PubMed][CrossRef]

23. Skirbekk B, Hansen BH, Oerbeck B et al. Motor impairment in children with anxiety disorders. Psychiatry Res 2012; 198: 135-9. [PubMed][CrossRef]

24. Kleve RAT. Motoriske vansker og selvopplevd kompetanse : En kvantitativ studie med barn i alderen 8-11 år. Masteroppgave. Oslo: Universitetet i Oslo, 2012. https://urn.nb.no/URN:NBN:no-33738 (5.3.2019).

25. Brown PM, Cornes A. Mental health of deaf and hard-of-hearing adolescents: what the students say. J Deaf Stud Deaf Educ 2015; 20: 75-81. [PubMed][CrossRef]

26. Dammeyer J. Psychosocial development in a Danish population of children with cochlear implants and deaf and hard-of-hearing children. J Deaf Stud Deaf Educ 2010; 15: 50-8. [PubMed][CrossRef]

Publisert: 27. mai 2019. Tidsskr Nor Legeforen. DOI: 10.4045/tidsskr.18.0939

Mottatt 4.12.2018, første revisjon innsendt 14.2.2019, godkjent 5.3.2019.

(C) Tidsskrift for Den norske legeforening 2020. Lastet ned fra tidsskriftet.no 